\title{
E-learning As an Innovation Model for Disabilities (Defective Vision)
}

\author{
Siti Fatihaturrahmah Al.Jumroh \\ s.vatyh28@gmail.com \\ Nouval Rumaf \\ ovha12015@gmail.com
}

\section{Universitas Pendidikan Muhammadiyah Sorong}

\begin{abstract}
Permenristekdikti number 46 of 2017 concerning Special Education and Special Services in Higher Education. It is intended that students with disabilities can obtain educational services according to their needs, so that they can learn and achieve optimal academic achievement. There are many ways or solutions that are tried to be given for students with disabilities so that obstacles in the learning process can be minimized, but these methods do not go far to help solve the difficulties faced by students with disabilities. One of the ways or solutions given is that students with disabilities also need to be proactive and communicative in lectures or students must interact actively in social relationships which are commonly called SKSD. But that doesn't help much. Therefore, The proponent develops an e-learning innovation model that aims to embrace all students, both students with disabilities and general students, to both learn and get the same education without having to have differences and difficulties. The results obtained from this application are that this innovation model is applied to language skills courses, students with disabilities who initially do not have self-confidence after attending this lecture become confident and of course the sense of difference no longer occurs, in the end students' learning abilities and achievements both students with disabilities and general students can increase.
\end{abstract}

Keywords: Learning Innovation Model; E-learning; Disabilities

\section{INTRODUCTION}

Education is currently very demanding for education actors to have more abilities and skills and be able to innovate to face challenges in a more challenging era, especially in the world of education. Lecturers or educators are required not only to have the ability in their field, but lecturers are also required to be creative in designing a lesson that can achieve learning goals easily and impressively. The problem faced today is the existence of two characteristics of students who generally have studied together in a university. The two types of students are general students with students with special needs. Often these two types of students are treated the same without examining their ability to receive lecture material. Which students with special needs are often left behind in obtaining 
material because they are faced with their disabilities. So that the impact that appears, the achievements of students with special needs are always left far behind than students in general.

On the basis of these problems, a learning model is created that can embrace both parties without any differences. The learning model is a learning innovation model based on e-learning for students with disabilities in language skills courses. This innovation model is designed as a solution to the problems faced by students with disabilities in their obstacles to receiving lecture material. the achievements of students with special needs are always left far behind than general students. On the basis of these problems, a learning model is created that can embrace both parties without any differences. The learning model is a learning innovation model based on e-learning for students with disabilities in language skills courses. This innovation model is designed as a solution to the problems faced by students with disabilities in their obstacles to receiving lecture material. the achievements of students with special needs are always left far behind than general students.

\section{LITERATURE REVIEW}

\section{Learning Innovation Model}

The term "model" is defined as a conceptual framework that is used as a guide in carrying out activities. In learning the term model is defined as a conceptual framework that describes a systematic procedure for organizing learning experiences to achieve certain learning goals. This is in line with the statement that the learning model is the entire series of teaching material presentations which includes all aspects before being and after learning by the teacher and all related facilities that are used directly or indirectly in the teaching and learning process (Istarani, 2012: 58).

The function of the Learning Model is as a guide for teachers and teachers in carrying out learning. This shows that each model that will be used in learning determines the devices used in the learning (Shoimin, 2014: 68). Talking about innovation, actually this word is often associated with change, but not every change is said to be an innovation. Innovation is an idea, discovery or method that is felt or observed as something completely new to someone who is relative. While the learning innovation referred to here is a teacher's method or tips in teaching students with certain goals.

Everyone naturally possesses the power of creativity and innovation. But the growth and development of each person will be different depending on the opportunity for each to develop it. The development or flourishing of creativity and innovation in each person or in connection with the work of the teacher is through continuous practice. This exercise must also be accompanied by the cultivation of noble attitudes and values, namely the attitude of a scientist and values based on IMTAQ. 
Innovation is an idea, invention or method that is felt or observed as something completely new to someone who is relative. While the learning innovation referred to here is a teacher's method or tips in teaching students with certain goals. Furthermore, Wina Sanjaya in her book curriculum and learning, innovation is defined as something new in certain social situations and is used to answer or solve a problem. Literally innovation / innovation comes from the word to innovate which means making changes or introducing something new, innovation is sometimes interpreted as an invention, however, the meaning is different from discovery in the sense of discovery or Invention.

Based on several definitions of learning innovation, it can be concluded that learning innovation is an effort to update the various components needed in the delivery of subject matter in the form of knowledge from educators to students with the aim of improving the quality of education that takes place. There are things that need to be known in learning innovation, namely the role of lecturers. Lecturers have an important role in implementing learning innovation. The role of lecturers in implementing learning innovations, namely, 1) As a teacher, 2) As an educator, 3) As a developer of teaching materials, 4) As a development of learning methods 5) As a developer of learning strategies, 6) As a developer of learning media, 7) As a developer of learning methods. learning or evaluation assessor.

\section{E-Learning}

The learning system is used as a means for the teaching and learning process which is carried out without having to meet face to face directly between teachers and students (Ardiansyah, 2013). Michael (2013: 27) adds that learning is structured with the aim of using an electronic or computer system so that it is able to support the learning process. Furthermore, it is necessary to know the characteristics of e-learning according to Rosenberg (2001). E-learning characteristics are networked, which makes it able to quickly repair, store or retrieve, distribute, and share learning and information.

The characteristics of E-learning according to Nursalam (2008: 135) are 1) Utilizing electronic technology services, 2) Utilizing the advantages of computers (digital media and computer networks) 3) Using self-learning materials which are then stored on the computer, so that can be accessed by doesen and students anytime and anywhere. 4) Utilizing the learning schedule, curriculum, learning progress results, and matters related to educational administration can be viewed at any time on the computer. The benefits of e-learning are 1) Flexible, 2) Independent Learning, 3) Cost Efficiency.

Furthermore, Sujana said that the advantages of e-learning are providing flexibility, interactivity, speed, visualization through various advantages of each medium (Sujana, 2005: 253). Furthermore, behind the advantages, there must be drawbacks. The weakness in question is that according to L. Gavrilova (2006: 
354 ) is that learning with the E-learning model requires more additional equipment.

\section{Students with Disabilities}

Disability is a new term to replace people with disabilities. Persons with disabilities can be defined as individuals who have physical or mental / intellectual limitations. Students with disabilities (persons with disabilities) are those who experience difficulties, obstacles or inability to carry out certain activities / functions so that they need special tools, environmental modifications or certain alternative techniques so that they can learn and participate fully and effectively in social life. Among them are those who experience obstacles in visual function (blind), obstacles to hearing and speech functions (deaf), obstacles to physical-motor function (disabled), emotional and behavioral disorders (hearing impaired), autism spectrum disorders, and others.

However, citizens with disabilities have the same rights to obtain education at various types and levels. State guarantees and recognition of their rights to educational services include the 1945 Constitution, Law Number 39 of 1999 concerning Human Rights, Law Number 8 of 2016 concerning Persons with Disabilities, Law Number 20/2003 regarding the national education system, and a series of other regulations in the form of government regulations and ministerial regulations.

In the process of fulfilling this, the government has issued various kinds of regulations and services, one of which is stated in Permenristek Dikti number 46 of 2017 concerning Special Education and Special Services in Higher Education. It is intended that students with disabilities can obtain educational services according to their needs, so that they can learn and achieve optimal academic achievement. There are many ways or solutions that are tried to be given for students with disabilities so that obstacles in the learning process can be minimized, but these methods do not go far to help solve the difficulties faced by students with disabilities. One of the ways or solutions given is that students with disabilities also need to be proactive and communicative in lectures or students must interact actively in social relationships which are commonly called SKSD. But that doesn't help much.

\section{METHOD}

The sample used in this study were 30 students of the Primary School Teacher Education Study Program, consisting of general or non-disabled students and students with special needs or disabilities. In applying the e-learning innovation model for students with disabilities, researchers used direct methods, namely methods that directly applied the innovation model to the object under study. The application begins with making an e-learning system application that will be used 
and then applying it to language skills courses to be practiced directly by students, both students with disabilities and general students.

\section{RESULT AND DISCUSSION}

After implementing the e-learning innovation model for students with disabilities and students without disabilities through language skills courses. The results obtained are as follows:

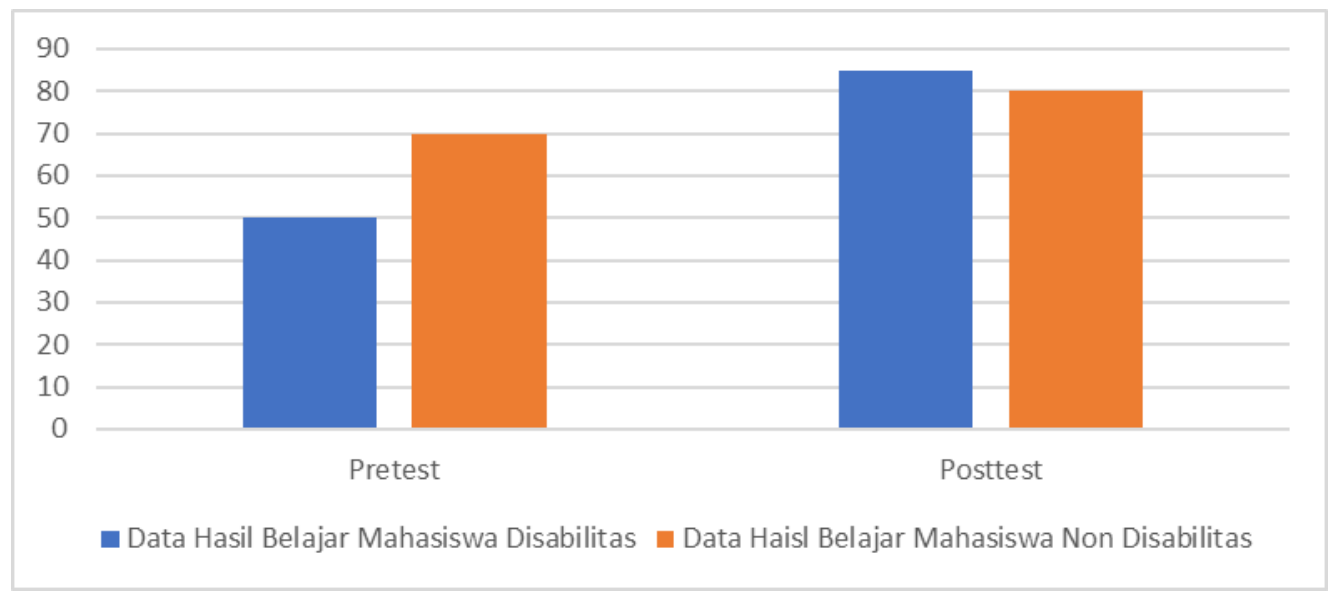

Figure 1: Data on Learning Outcomes of Students with Disabilities and NonDisabilities

Based on this chart, it is known that students with disabilities and nondisabled or general students at the pretest stage show that the learning outcomes of students with disabilities get lower graphs than general or nondisabled students. A different thing happened after the implementation of the e-learning innovation model for the two students. It can be seen in the graph that students with disabilities have a significant increase, which is not much different from non-disabled students, namely 85:80.

Furthermore, from these results it can be concluded that e-learning makes students with disabilities feel that they will not be left behind in following learning materials because students can participate in repeated learning. So, after participating in this activity, students with visual impairments have a strong sense of self-confidence and motivation to improve their performance without any differences. The benefits that are not much different are also felt and obtained by general students, namely that general students can easily access lecture material anywhere and anytime without being limited by space and time. In addition, the results felt by their students felt that learning online had more convenience and was more fun than ordinary learning. Students in addition to participating in their learning will also experience interactive entertainment at the same time so that they will not feel bored in participating 
in this e-learning (flexible) learning. The end of this lesson, of course, can increase his understanding and achievement.

In general, the results of the application of this learning innovation model are as follows:

1. Increased active participation of students.

2. Increased students' independent learning abilities.

3. Improve a quality of teaching materials as well as training.

4. Foster self-confidence

5. The loss of difference between dissability students and general students (having equal opportunities in learning)

6. Reducing costs for learners, namely transportation and accommodation costs

\section{CONCLUSION}

Learning innovation can be interpreted as a new effort in the learning process, using various methods, approaches, means and a supportive atmosphere to achieve learning objectives. E-learning learning is learning that is on a network arranged using an electronic or computer system so that it is able to support the learning process. Meanwhile, students with disabilities (persons with disabilities) are those who experience difficulties, obstacles or inability to carry out certain activities / functions so they need special tools. Based on application innovationelearning learning for students with disabilities produces positive things, namely 1) Increased active participation of students, 2) Increased students' independent learning abilities, 3) Improving the quality of teaching materials as well as training, 4) Fostering self-confidence, 5) Loss differences between students with disabilities and general students (having equal opportunities in learning), 6) Reducing costs for learners, namely transportation and accommodation costs.

\section{REFFERENCES}

Istarani. (2012). Model Pembelajaran Innovatif. Medan. Media Persada.

Shoimin. (2014). Model Pembelajaran Innovatif dalam Kurikulum 2013. Yogyakarta. Ar-Ruzz Media.

Sanjaya, Wina. (2008). Kurikulum dan Pembelajaran (Teoritik dan Praktik Kurikulum KTSP). Jakarta: Prenada Media Group.

Allen, Michael. (2013). Michael Allen's Guide to E-learning. Canada: John Wiley \& Sons.

Ardiansyah, Ivan. (2013). Eksplorasi Pola Komunikasi dalam Diskusi Menggunakan Model pada Perkuliahan Simulasi Pembelajaran Kimia, Universitas Pendidikan Indonesia, Bandung-Indonesia. 
Chandrawati, Sri Rahayu. (2010). Pemanfaatan E-learning dalam Pembelajaran. No 2 Vol. 8.

L. Tjokro, Sutanto. (2009). Presentasi yang Mencekam. Jakarta: Elex Media Komputindo.

L. Gavrilova, Marina. (2006). Computational Science and Its Applications ICCSA 2006: 6th International Conference. Glasgow, UK: Springer.

Nursalam dan Ferry Efendi. (2008). Pendidikan dalam Keperawatan. Jakarta: Salemba Medika.

Pranoto, Alvini.dkk. (2009). Sains dan Teknologi. Jakarta: PT Gramedia Pustaka Utama.

Sujana, Janti Gristinawati dan Yuyu Yulia. (2005). Perkembangan Perpustakaan di Indonesia. Bogor: IPB Press. 